Click www.researchjournal.co.in/online/subdetail.html to purchase.

\title{
Sensory evaluation of kinnow powder
}

Dhruv Juyal

Received : 08.01.2018; Revised : 14.02.2018; Accepted : 23.02 .2018

Author for Correspondence :

\section{Dhruv Juyal}

Department of Processing and

Food Engineering, Punjab

Agricultural University,

Ludhiana (Punjab) India

Email: dhruvjuyal@gmail.com
- ABSTRACT : The maximum values of correlation co-efficient between sensorially evaluated fresh juice and reconstituted juice were $(0.28)$ for colour at 35:65 blend, $(0.48)$ for flavour at 35:65 and 37.5:62.5 blend, $(0.24)$ for consistency at 40:60 blend and (0.48) for overall acceptability at 35:65 blend.

- KEY WORDS : Kinnow powder, Sensory evaluation, Reconstituted juice, Fresh kinnow juice, Flavour

- HOW TO CITE THIS PAPER : Juyal, Dhruv (2018). Sensory evaluation of kinnow powder. Internat. J. Agric. Engg., 11(1) : 90-94, DOI: 10.15740/HAS/IJAE/11.1/90-94. 